\title{
Franz Grillparzer's and Lion Feuchtwanger's \\ Die Jüdin von Toledo
}

\author{
Kristina R. Sazaki
}

Critics often compare different treatments of a particular literary theme to reveal aspects of the creative process. Such an analysis can also provide a means to establish how male authors have maintained their female figures within the established patriarchal discourse of writing. An example is the account of the twelfth-century Spanish King Alfonso VIII. ${ }^{1}$ The married king of Castille falls in love with a Jewess from Toledo, takes her as his mistress, and spends the next seven years with her, neglecting his duties and kingdom. In order to bring the king back to the realm, the grandees kill the Jewess and all those near her. This chronicle has served as a basis for several literary texts, notably Lope de Vega's La paces de los reyes, y la Judia de Toledo (1616), Jacques Cazotte's Rachel ou la Belle Juive (1778), Johann Christian Brandes's Rahel, die schöne Jüdin (1789), Franz Grillparzer's Die Jüdin von Toledo (ca. 1851), and Lion Feuchtwanger's Die Jüdin von Toledo (1954).

A comparison of Grillparzer's and Feuchtwanger's versions of this historylegend will serve to illustrate the unchanging image of women within the maleauthored text. One might expect to encounter two very different attitudes in these texts considering that Grillparzer was an Austrian Catholic experiencing the Metternich Era, while Feuchtwanger was a German Jew who survived the Holocaust. The anonymous foreword to the Fischer edition of Feuchtwanger's novel states that the main difference between these two texts is that Grillparzer's drama was not told from the Jewish perspective:

[A]lle Konzentration galt dem Christen Alfonso, die Jüdin Raquel wurde - dem stets übernommenen Titel zum Trotz - Schritt um Schritt an den Rand gedrängt, diente nur noch der Begründung der Katharsis des Königs. Desto wichtiger wurde Lion Feuchtwanger dieser ausgleichende Roman. ${ }^{2}$

Indeed, Feuchtwanger's reworking of Grillparzer's play, which he admired greatly, ${ }^{3}$ exposes his desire to emphasize Jewish issues, especially in the figure

1. Charlene Lea, Emancipation, Assimilation and Stereotype: The Image of the Jew in German and Austrian Drama (1800-1850), (=Modem German Studies 2) Bonn 1978 , p. 70, points out the difficulty of establishing the historical accuracy of this legend.

2 Foreward, Die Jüdin von Toledo, by Lion Feuchtwanger. Frankfurt/M. 1983.

3. Lion Feuchtwanger, Nachwort des Autors 1955, Die Jüdin von Toledo. 
of Raquel. In fact, the prevalence of the title Die Jüdin von Toledo over Feuchtwanger's original title, Spanische Ballade, invites a comparison between his and Grillparzer's Jewess which up to now has been overlooked. There exists an affinity between Grillparzer's Rahel and Feuchtwanger's Raquel which truly binds the two works.

The restriction of the image of woman to the madonna/whore dichotomy is imbedded in the patriarchal discourse of literature. Neither Grillparzer nor Feuchtwanger veers from a rigid image of woman they have each formed that gives neither Jewess an independent voice within the text. Rahel and Raquel's outward dissimilarities immediately expose such a dichotomy. Rahel is fiery, sensual, an obvious outsider, while Raquel is an innocent child, an idolizer of her father, Jehuda.

For Grillparzer, his image of Jewish women is closely linked to his writing of Die Jüdin von Toledo and his trip to Germany in 1826. In sketching out the first scene of the play in his diary in 1824, Grillparzer described Rahel: "[I]hre Arme umfassen seine Füße, ihr üppiger Busen wogt an seine Kniee gepreßt und der Schlag ist geschehn. Das Bild dieser schwellenden Formen, dieser wogenden Kugeln (unter diesem Bilde sind sie seinen Sinnen gegenwärtig) verläßt ihn nicht mehr." ${ }^{4}$ While visiting the Prague ghetto on his way to Berlin in 1826 , he noted in his diary: "[...] sah ich 3 der schönsten Mädchen, die ich je gesehen, in dieser Judenstadt, und alle 3 offenbar Jüdinnen. Die eine beinahe griechisch und ideal, die andern menschlich, leiblich, fleischlich, was man will, aber äußerst hübsch." 5 urely he sought and found personifications of his literary Rahel in these women.

Some critics have seen in Marie von Smolenitz the model for the figure of Rahel. ${ }^{6}$ However, the importance of Rahel Levin Varnhagen for Die Jüdin von Toledo has been underestimated. ${ }^{7}$ Grillparzer met her while on the aforementioned trip to Berlin in 1826. That this visit is not characterized in Grillparzer's diary is understandable since he was unable to write at the time due to a severe cut to his right index finger. ${ }^{8}$ However, other facts point to Rahel's

Frankfurt/M. 1983.

4. Franz Grillparzer, Sämtliche Werke, 4 vols., ed. Peter Frank and Karl Pörnbacher. München 1961-65, vol. 4, p. 382. All subsequent quotations (except for Die Jüdin von Toledo) will be noted under $G W$.

5. GW vol. 4, p. 409.

6. $G W$ vol. 2 , p. 1261 ; Lea, p. 71 .

7. Lea, supporting the claims of Dorothoy Lasher-Schlitt, writes: "Grillparzer's acquaintance with modern, assimilated Jewish women like Josephine von Wertheimstein, Petty Paoli and Rahel Varnhagen had no appreciable influence on his characterizations of Jewish women." Lea, p. 70.

8.

$G W$ vol. 4 , p. 422 . 
lasting impression on him as well as a connection between her and the writing of Die Jüdin von Toledo. For one, the list of "Stoffe" he entered into his diary at the end of 1826 - after his trip to Berlin - includes Die Jüdin von Toledo. ${ }^{9} \mathrm{He}$ also read Rahel's letters, published after her death in 1833, and wrote notes on them..$^{10}$ He obviously mentioned his meeting with Rahel to others, including Baroness Jenny von Gustedt. ${ }^{11}$ Although the accuracy of Baroness von Gustedt's account may be suspect, her mention of Grillparzer's meeting further suggests his positive reaction to meeting Rahel.

Grillparzer's own description of Rahel Levin can be found in his Selbstbiographie (1853). He had already been asked on January 1, 1849 (and again at the beginning of 1852 and 1853) to provide the Österreichische Akademie der Wissenschaften with detailed biographical information. ${ }^{12}$ This was also the time during which he was working intensively on Die Jüdin von Toledo. ${ }^{13}$ Grillparzer's recollection of Rahel for the Selbstbiographie must have influenced his depiction of the literary Rahel. His description of meeting Rahel Levin is very informative. Although Grillparzer was very tired at the time of the meeting, Rahel's presence quickly changed his mood:

Nun fing aber die alternde, vielleicht nie hübsche, von Krankheit zusammengekrümmte, etwas einer Fee, um nicht zu sagen Hexe ähnliche Frau zu sprechen an, und ich war bezaubert. Meine Müdigkeit verflog, oder machte vielmehr einer Art Trunkenheit Platz. Sie sprach und sprach bis gegen Mitternacht, und ich weiß nicht mehr, haben sie mich fortgetrieben, oder ging ich von selbst fort. Ich habe nie in meinem Leben interessanter und besser reden gehört. ${ }^{14}$

Grillparzer certainly demonstrates an undeniable admiration for the individual talents of this singular woman. Rahel Levin's position as an outsider within Berlin society certainly impressed him. However, the imagery he uses finds echo in long-established images of Jews as witches. ${ }^{15}$ The link between Jew and witch

9. $G W$ vol. 4 , p. 422.

10. $G W$ vol. 3, p. $798-800$.

11. $G W$ vol. 4 , p. 921 .

12. $G W$ vol. 4 , p. 841,991 .

13. $G W$ vol. 2 , p. 1261.

14. $G W$ vol. 4 , p. 137.

15. Venetia Newall has summarized various European superstitions relating Jews with witches. Her examples include the Judenhut, prescribed during the Middle Ages in Austria, Hungary, and Germany (Vienna Council of 1267). This hat was "usually 
is strengthened by the mutual persecution they suffered, both as representatives of social non-conformity. ${ }^{16}$

In his description of Rahel Levin, Grillparzer appears to combine the ideas of Jew and witch as non-conformists. Rahel Levin is old, resembles a fairy, even a witch and has completely bewitched the visitor. There is definitely a "Verdacht der Zauberei" about her. However, this term was used by Grillparzer not to describe Rahel Levin rather his literary Rahel in the sketch of $1824 .{ }^{17}$ Here it seems that Grillparzer sought and found some confirmation of his literary creation.

The non-conformist, be she Jew or not, continued to seduce Grillparzer. His friendship with Katharina Fröhlich comes to mind. However, he was to continue this affiliation with her in such a way as would never allow an unconventional marriage. He wrote to Georg Altmütter around 1821 about his inability to love:

Ich glaube bemerkt zu haben, daß ich selbst in der Geliebten nur das Bild liebe, das sich meine Phantasie von ihr gemacht hat, so daß mir das Wirkliche zu einem Kunstgebilde wird, das mich durch seine Ubereinstimmung mit meinen Gedanken entzückt, bei der kleinsten Abweichung aber nur um so heftiger zurückstößt. ${ }^{18}$

Grillparzer appears to have done the same with Rahel Levin. He has created a Kunstgebilde which can no longer be differentiated from the character of Rahel: the provocative outsider who remains on the edge of society, even for her admirers. The interdependence of the two Rahels for Grillparzer is evident. Occupation with the one Rahel is often followed by occupation with the other to such a degree that the relationship cannot be denied.

For Feuchtwanger, his strict Jewish upbringing informed his view of Jewish women. The many Jewish motifs that reoccur in his works can be traced back to his deep knowledge of the Old Testament. ${ }^{19}$ In the afterword to his Die Jüdin von Toledo, Feuchtwanger points out the analogy between the biblical Esther and his own work. ${ }^{20}$ In the Book of Esther, the beautiful virgin is chosen to be presented to King Ahasuerus after Queen Vashti falls into disgrace. Because of her beauty, Esther becomes the new queen. The king is persuaded by his first

red, the brim shaped to resemble a pair of horns." Undoubtedly, the horns were to be associated with the devil. Venetia Newall, "The Jew as Witch Figure," The Witch Figure, ed. Venetia Newall, London 1973, p. 104.

16. Newall p. 107.

17. $G W$ vol. 4, p.381.

18. $G W$ vol. 4 , p. 762 .

19. Walter A. Berendsohn, "Lion Feuchtwanger and Judaism," Lion Feuchtwanger: The Man, His Ideas, His Work, ed. John M. Spalek, (=University of Southern Califomia Studies in Comparative Literature 3) Los Angeles 1972, p. 27.

20. Feuchtwanger, Nachwort p. $463 \mathrm{f}$. 
minister, Haman, to issue an edict of extermination of all the Jews of the kingdom. Esther, sacrificing herself for her Jewish people, follows her guardian Mordacai's advice and appears uninvited before the king. She eventually reveals her origin to the king, who has Haman executed. Esther's request is fulfilled, and the edict of destruction is changed into permission for the Jews to avenge themselves on their enemies. Feuchtwanger brings up an aspect of Esther's character in the Bible which he felt had up to that time hindered later writers from adapting the story: "Esther ist eine Puppe in der Hand ihres Vormunds, sie wird von außen bewegt, sie ist ganz und gar passiv, ein Rad im Getriebe der Handlung, nichts weiter."21

Because of this statement, one might conclude that Feuchtwanger's Raquel differs from her model. One would expect her to be active and not a mere tool of her guardian. However, one biblical description of Esther helps to reveal her essence Feuchtwanger never denies in his portrayal of Raquel: "Esther obeyed Mordecai just as when she was brought up by him" (Esth 2: 20). This acceptance of male authority (Mordecai being Esther's adopted father) conflicts with the above assumption that Feuchtwanger would be successful in portraying Raquel as capable of standing up to this authority. Instead, he remained indebted to this Jewish concept of familial authority.

The personal images of Jewish women held by Grillparzer and Feuchtwanger call into question their ability to depict women with independent, complex, or whole personalities. Viewing the major female figures in the two texts will show that they are weak when it comes to displaying their individuality, to facing male authority, and to empowering themselves.

The lack of personality both Rahel and Raquel exhibit is closely bound to the male authority to which they are subject. From the first scene of Grillparzer's play, in which Rahel illegally enters the royal garden, her resistance to her father, Isaak, is obvious. Since Jews are not allowed in the garden, Rahel's move could also be interpreted as one against the paternalistic aspects of Jewishness. As Dagmar Lorenz has shown, Grillparzer's female characters often are used to expose western society as oppressive and misogynist. ${ }^{22}$ Their actions attempt to overturn or upset the patriarchy. However, Lorenz has overlooked Rahel's liaison with King Alfonso. A closer look at this relationship reveals that Rahel's conduct exhibits an acceptance of the king's authority. Everyone - including Rahel - is the king's subject, which he himself stresses upon his first entrance: "Denn wer mich

21. Feuchtwanger, Nachwort p. 464.

22. Dagmar C. G. Lorenz, "Frau und Weiblichkeit bei Grillparzer," Der widerspenstigen Zähmung: Studien zur bezwungenen Weiblichkeit in der Literatur vom Mittelalter bis zur Gegenwart, ed. Sylvia Wallinger and Monika Jonas Innsbruck 1986, p. 207. 
einen König nennt, bezeichnet / Als Höchsten unter Vielen mich . .."23 As the highest authority, Alfonso is the one to whom Rahel must ultimately turn when she seeks protection from the guards (I: 311 ). She abandons one authority - her father - only to subjugate herself immediately to another.

The case for Raquel is even more convincing. She consistently adapts quickly to any new situation without question. The move from liberal Seville to Catholic-dominated Toledo becomes for Raquel a simple matter of changing her name: "Es war alles wie in Sevilla, sogar die Wanne, in der sie lag. Aber sie selber war keine Rechja mehr, sie war Doña Raquel." ${ }^{24}$ Her immediate concern is for the reputation of her father. She asks herself: "Werden diese Christen verstehen, was für ein großer Mann ihr Vater ist?" (38). Only after she voices concern for her father does she ask whether the Christians will understand her different nature. Of course, her different nature is also different for her, for she is now openly a practicing Jew. She had had no difficulty as a child accepting the change from being a Muslim to a Jew because her father, who had lived as a Muslim in Seville to save his fortune, so wished it:

Und als sie ihn einmal geradezu fragte, was sie glauben und was sie tun solle, hatte er freundlich erwidert, da sei kein Zwang; wenn sie erst erwachsen sei, dann möge sie selber entscheiden, ob sie die hohe, doch nicht ungefährliche Verpflichtung heimlichen Judentums auf sich nehmen wolle. (38)

Her father Jehuda convinces her in the same manner to accept King Alfonso as her lover by emphasizing the sacrificial nature of this deed: "Wenn du sagst: Dieser Mann ist mir ein Abscheu, dann nehme ich dich bei der Hand und rufe deinen Bruder Alazar, und wir machen uns fort [...] Mag dann der Mann [Alfonso] hier wüten, und mag dann Unglück kommen über Tausende" (158). The "choices" Jehuda gives his daughter are formulated such that she cannot refuse to fulfill his wishes. In this way, Raquel's identity is established through her father. When Jehuda was a Muslim, Raquel was a Muslim. When he became a Jew, she became a Jew. When it became advantageous for Jehuda to become the king's minister, it became appropriate for Raquel to become the king's lover. Jehuda's victimization of his daughter is criticized in the text but Raquel's submission to his authority is not. As she herself states: "Was mein Vater tut, ist recht, und wie er tut, will auch ich tun" (41).

Raquel moves with Alfonso into the Galiana, the arabic Lustschloß he had

23. Franz Grillparzer, Die Jüdin von Toledo, Sämtliche Werke, 4 vols., ed. Peter Frank and Karl Pörnbacher. München 1961-65. Act I: 96-97. All subsequent quotations will be cited accordingly (act: verse line).

24. Lion Feuchtwanger, Die Jüdin von Toledo, Frankfurt/M. 1983, p. 37. All subsequent quotations refer to this edition. 
had renovated for her. She visits her father infrequently, but these visits give her strength:

In der Galiana war sie nur ein Teil Alfonsos gewesen, nicht sie selber; sie hatte Alfonsos Ganzheit bewundert und sich selber unterlegen gefühlt, weil sie zwiespältig war. In Gegenwart des Vaters wußte sie: ihre Zwiespältigkeit war Tugend, war ein, freilich verfängliches, Glück. (186)

One must question whether she is really herself in her father's presence. The reader is given no indication of what this self might be except that it is only viable in the presence of Jehuda. Raquel's inner conflict is only one of differentiating between the two authorities.

As in the play, there is in the novel a similar shift from the familial to the state authority, but it is only temporary. Sensing the upcoming murder, Jehuda asks his daughter to return with him and not remain in the king's castle. When she refuses - she must, for Alfonso has ordered her to stay (388) - Jehuda realizes and accepts that he has lost his control over Raquel to Alfonso: "Ich selber habe sie dem Manne übergeben [. . . ] ich darf nicht klagen, wenn sie mich jetzt sterben läßt, ehe sie handelt gegen den Wunsch des Mannes" (385). But, the lesson Alfonso learns after the deaths of Raquel and Jehuda is that Raquel never belonged to him in the first place. Although the two were buried initially in the Galiana, where they had been murdered, Alfonso reconsiders this burial. Speaking to Don Ephraim, the leader of the Jewish congregation, he says:

Mehrmals hab ich daran gedacht, sie auf meine Art zu bestatten und gemäß ihrem Stande. Aber ich habe es besser überlegt, und es scheint mir richtiger, daß ihr meinen toten Escrivano begrabt auf eure Weise und mit euern Ehren, ihn und auch Doña Raquel, seine Tochter, die mir sehr nahestand. Sie gehören zu euch, beide, sie gehörten bis zuletzt zu euch, und ich werde dir dankbar sein, wenn du es mit ihrer Bestattung so hältst, wie sie selber es wünschten. (452)

Raquel is symbolically handed back to her father and the Jewish faith. The lesson the reader learns is that Raquel is visible only in the light of her father and his religion.

Fainting as a means to express woman's powerlessness has been employed often in literature. ${ }^{25}$ If one reads the German Ohnmacht - ohne Macht figuratively, it illustrates the significance of this act. In the texts under discussion, fainting is used to place the women in similar situations as martyrs. In the novel, Raquel faints twice. She first faints directly after agreeing to become Alfonso's mistress (158). Later, she faints after agreeing to allow her father to

25. Examples include Sophie von La Roche's Fräulein von Sternheim, Goethe's Gretchen, Heinrich von Kleist's Marquise von O., and Louise Aston's Lydia. 
take her son to safety among other Jews (339-40). Jehuda sees in Raquel's fainting an envious ability to flee misery: "[E]r beneidete sie. Ihm war es versagt, in solche Ohnmacht zu flüchten, er mußte sein Elend in Bewußtsein zu Ende kosten" (340). However, Raquel must deny her own real wishes. The only way in which she can be empowered is to sacrifice herself to save others. Sacrifice is her foremost quality. It is no wonder she is called Lämmchen by her nurse (54).

In the play, the act of fainting is inverted, but the results are the same. Here, Rahel's sister, Esther, faints when Rahel is taken away to be murdered and admonishes herself for this. By fainting, she has only saved herself: "Und ich Feige, / Ich fiel in Ohnmacht, als es galt / Mein Leben für die Schwester hinzugeben, / Zu sterben wenigstens zugleich mit ihr. / Als ich erwachte, war die Tat geschehn [...]" (V: 1604-08). She regrets not serving as martyr. Rahel, on the other hand, does not faint and does not save herself. She is sacrificed in order to save the state, just as Raquel was.

Nevertheless, Rahel's martyrdom is tempered by an implicit participation in King Alfonso's downfall. The scene in which Rahel steals the portrait of the king and dances with it reflects not only her desire to turn appearance into reality but also reflects the disturbed order of the state. ${ }^{26}$ On a more basic level, Rahel causes the subsequent events with this theft. Both the stage directions and Rahel's own words underscore the fact that the portrait is no longer in its frame: "Rahel (kommt zurück mit einem Bild ohne Rahmen) / Hier ist des Königs Bild, gelöst vom Rahmen" (II: 568). The order of the state is represented in the rigid frame which keeps the portrait - and with it the weak king - in check. Rahel dares to upset the status quo and must suffer the consequences. The stage directions at the beginning of Act V reinforce the symbolic nature of the portrait: "Rechts im Hintergrunde ein gleichfalls umgeworfener Tisch, darüber ein Gemälde, halb aus dem Rahmen herausgerissen." Although this scene takes place in another castle and the identity of the portrait is unclear (it may be the reclaimed portrait of the king), the fact that it is only halfway within the frame reveals the weakened condition of the state. Despite this attempt to reestablish the order (the murder of Rahel in the previous act), it can only be seen as halfway successful.

Rahel's responsibility, if questioned at various times by the reader/audience, is reasserted in her sister Esther's final speech, in which she lays blame for the misery on everyone, including Rahel: "Dann nehm ich rück den Fluch [auf den König], den ich gesprochen, / Dann seid Ihr schuldig auch, und ich - und sie [Rahel]. / Wir stehn gleich jenen in der Sünder Reihe" (V: 1944-47). Esther's transferring of the sins of her father Isaak - namely, his avarice - to herself and

26. Dieter Borchmeyer, "Franz Grillparzer: Die Jüdin von Toledo", in: Deutsche Dramen: Interpretationen zu Werken von der Aufklärung bis zur Gegenwart, 2 vols. Königstein/Ts. 1981, vol. 1, p. 217-220. 
Rahel might be interpreted by some as an act of forgiveness. However, this shift only underscores the inescapable connection between Rahel and blame. Esther is clearly a device Grillparzer used in order to harken back to the biblical Esther. This association emphasizes her pure and sacrificial nature and therefore puts her in opposition to Rahel. ${ }^{27}$ In this way, Grillparzer stresses Rahel's complicity even further.

Magic comprises an integral part of Rahel/Raquel's limited identity but is constructed in each text to stress either the woman's devilish or virginal qualities. Although Grillparzer's Jüdin relies less on Rahel's magical qualities than earlier versions had, ${ }^{28}$ his text still reveals an insistence on maintaining this image and thereby strengthening Rahel's complicity in the tragic events. As she fantasizes over the portrait of Alfonso, she remembers what witches are said to have done to pictures in order to achieve the desired results, pins the portrait to the back of the chair, and says: "O gäbe jeder dieser Stiche Blut, / Ich wollt' es trinken mit den durst'gen Lippen / Und mich erfreun am Unheil das ich schuf" (II: 590-92). Alfonso's reaction to secretly witnessing this scene - "übst du geheime Künste, die Verbrechen? / War's doch, als fühlt' ich in der eignen Brust, / Den Stich nach jenem Bild" (II: 631-33) - is his attempt to exonerate himself from his attraction to Rahel and later, when holding Rahel's picture, contends that Rahel's "Zauber" has taken hold of him: "Man spricht von magisch unerlaubten Künsten, / Die dieses Volk mit derlei Zeichen übt / Und etwas, wie von Zauber, kommt mich an" (II: 753-755). Grillparzer does not question the validity of Alfonso's assertions about Rahel's magical powers. Indeed, as mentioned earlier, he insists that a "Verdacht der Zauberei" be an integral part of the story. ${ }^{29}$ Grillparzer's refusal to separate the outsider from these qualities forces her into the specific "whore" category.

Like Rahel, Raquel has magical qualities. In contrast to Rahel, Raquel's magical abilities are unknown to her and are used with admirable ends in view. After her death, Alfonso tries to conjure up her image once more. At first he remembers how they met, how she had made fun of his northern castle, how it was her black magic that caused him to build the Galiana. However, when she appears a second time wearing the same expression as when he had raped her, he realizes the purpose of her "black magic;" to teach him, "was Verantwortung hieß,

27. It could be that the reason Grillparzer was unable to finish his version of the Esther story, Esther (ca. 1830-1848), was because he was unable to reconcile the biblical Esther with his image of a Jewish woman.

28. Kerstin Neye, "Versöhnung inmitten der Katastrophe: Die Jüdin von Toledo", in: Gerettete Ordnung: Grillparzers Dramen, ed. Bemhard Budde and Ulrich Schmidt, (=Historisch-kritische Arbeiten zur deutschen Literatur 7) Frankfurt/M. 1987, p. 219.

29. $G W$ vol. 4 , p. 381 . 
was Schuld hieß" (415). Later, Raquel's Jewish friend, Don Benjamin, reiterates the function of her magic: "Der König hatte sich gewandelt. Raquel hatte es erreicht. Es war zugegangen wie in jenem Märchen, das sie so sehr liebte. Der Zauberer hatte dem Lehmkloß Leben eingehaucht, aber der Zauberer war darüber gestorben" (458).

The men who have most control over the Jewesses at first appear to share the blame in their deaths. However, they, through the act of cleansing, enable themselves to wash away their sins and continue on. For Grillparzer, this is most evident in King Alfonso; for Feuchtwanger this is seen in Raquel's father, Jehuda.

Dieter Borchmeyer has already pointed out that Grillparzer's Alfonso performs two acts of sacramental purification. ${ }^{30}$ The first incident occurs after the decision has been made to murder Rahel. Alfonso says to Queen Eleonore: "Ich spreche mich von meinen Sünden los" (IV: 1410). The second incident occurs when he washes himself in pantomime after seeing Rahel's dead body (V: 1812ff.) Alfonso reveals the success of his acts of purification shortly thereafter in a remark to his liege and friend, Garceran: "Und hast du dich gereinigt so wie ich" (V: 1906). This is a statement of success and not intent. Alfonso's grand act of repentance: "Denn wie die Pilger mit dem Kreuz bezeichnet / Zur Buße hinziehn nach Jerusalem, / So will ich, meiner Makel mir bewußt [. . .]" (V: 1884-86) rings hollow as the rhetoric of convention takes over. The sincerity of his speech becomes suspect. As is so often the case with Grillparzer, gestures (in this case the act of purification) contradict the spoken words and reveal them to be untrustworthy. Seen in this light, Alfonso's relinquishment of personal power means very little and supports Lorenz's claim that the power structure remains unchanged: "Wer aber anders als der korrupte Hof wird den Kinderkönig erziehen und regieren? Die Verbrecher, die fünf Akte lang agiert haben, werden das Kind in ihrem Sinne konditionieren." 31

Grillparzer seems to minimize Alfonso's accountability on several occasions. Firstly, he has Alfonso excuse Garceran's abominable behavior toward Dona Clara, one of the queen's ladies-in-waiting. Alfonso's legitimization of Garceran's indiscretion (I: 235ff.) only foreshadows the acceptability of his own behaviour later on. Secondly, Grillparzer emphasizes Alfonso's own pure, almost virginal qualities in order to grant him this one transgression. When Alfonso decides to bed Rahel, he asks Garceran for advice: "Wie fängst dus an? Belehre mich ein wenig / Ich bin ein Neuling in dergleichen Dingen, / Nicht besser als ein großgewachsnes Kind" (II: 451-53). Finally, in her final speech, Esther places blame upon herself and her family, thereby lessening Alfonso's role in the murder.

30. Borchmeyer, p. 227-228.

31. Dagmar C. G. Lorenz, Grillparzer: Dichter des sozialen Konflikts, Literatur und Leben, (=Neue Folge 33) Wien 1986, p. 110. 
Jehuda uses the symbolic washings in the same way as his Christian counterpart. While contemplating whether to allow Raquel to become Alfonso's mistress, Jehuda recalls his many affairs:

Er hatte sich ergötzt mit Tänzerinnen aus Kairo und aus Bagdad, mit Huren aus Cádiz, die berühmt waren um ihrer Künste willen; oft aber hernach hatte er Uberdruß gespürt und immer hatte er in fließendem Wasser gebadet, ehe er wieder vor das reine Gesicht seiner Tochter trat. (152)

Ritual bathing in running water for the purpose of spiritual purification was prescribed by Jewish law for any man who had discharge from his sexual organs (Lev. 15:13). If he emitted semen, he bathed his whole body in water (Lev. 15:16). Cleansing himself allows Jehuda to forgive himself an act he otherwise deemed admonishable. These ritual acts of purification provide Jehuda with the excuse he needs to allow Alfonso to take Raquel as his mistress. She, too, can purify herself and does so by bathing in rose water before and after sleeping with Alfonso (165). Her bathing obviously relieves Jehuda of any responsibility, but the fact that she washes herself twice a day suggests bathing to be less effective for her than her father. Not only must she wash herself after intercourse, but she must also purify herself after contact with the Christian, Alfonso. ${ }^{32}$ Raquel maintains her virtue and purity - and with that her madonna image - by bathing.

The power and machinations of the queen in both texts seem to contradict the thesis that woman has no voice. The queen wields influence among the court officials, the grandees, and is instrumental in bringing about Rahel/Raquel's death as well as restoring the order of the state as much as possible. However, in neither text does the queen act outside the bounds of her relationship to her husband. Since the king is depicted mainly when he is not performing royal duties, his wife fulfills these duties. Grillparzer's Eleonore and Feuchtwanger's Leonor are in essence that conscientious component of each king's existence; the royal duty to the state. The queen personifies the aspect of the man's personality he has neglected since meeting the Jewess.

Simply put, the queen indicates the divided mind of the king. Eleonore turns away from Rahel when Rahel first appears in the garden and asks for sanctuary from the guards. Rahel then turns to the king (I: 303-12). Borchmeyer misunderstands the queen's symbolic role in the play when he takes this episode as a cue to blame her for the ensuing affair: "Die Königin selbst treibt also indirekt die Verführerin in die Arme des Gemahls. ${ }^{\text {"33 }}$ In the novel, Leonor wants

32. Gentiles were considered impure. See "Purity and Impurity, Ritual," Encyclopedia Judaica, 1971 ed. Jews were also required to wash food bought from gentiles. See "Mikveh," Encyclopedia Judaica, 1971 ed.

33. Borchmeyer, p. 213. 
to invite the children of the new minister, Jehuda, to her castle (84). Since the king was slightly hesitant in doing so, he appears absolved of the affair. Both times, the queen has initiated contact between the king and the Jewess. As the responsible side of the king's mind, she would not enter into an affair with a Jewess, because this would bring down the state. Therefore, she relegates the Jewess to the irrational side, embodied in the king.

References in both texts depict the queen as a mere part of her husband's personality. Grillparzer's Alfonso calls Eleonore "kein mindrer Teil von meinem Wesen" (I: 98). Similarly, Leonor's likeness to Alfonso is clear: "Sie fühlte wie er" (80); "[S]ie war aus dem gleichen Stoff wie der König" (82). When seen in this light, the queen's complicity in the murder of the Jewess takes on greater meaning than that of a pure act of revenge. Acting as the rational side of the king, she basically performs the royal duties the irrational side of the man refuses to do; do away with the element that is preventing the proper ruling of the kingdom, that is, the Jewess.

In both texts, children - sons actually - play a role as woman is used as a tool to further dynastic claims. Eleonore has a son who will take over the reign of Castille. Alfonso can easily relinquish individual power since the dynastic power will be maintained. Lorenz suggests that Grillparzer does not restrict his female characters to their biological functions:

$\mathrm{Daß}$ Eleonore Mutter ist, ist für ihren Charakter nebensächlich, da ihre Mütterlichkeit als Verhaltensweise fehlt. Würde es keine politische Rolle spielen, daß sie Mutter des kleinen Prinzen ist, den sie tatsächlich als Druckmittel benutzt, käme dieses Faktum nicht zum Tragen. ${ }^{34}$

If the queen is interpreted as only the rational side of the man, as I contend, then her lack of biological function as well as her lack of "Mütterlichkeit" need not be called into question. Likewise, Raquel's son is kidnapped by Jehuda's friend and taken out of Toledo. Jehuda can easily relinquish personal life since his dynastic rule will be upheld.

The approximately one hundred years separating Grillparzer's and Feuchtwanger's works seemed to have had little impact on the later version as far as women are concerned. Yes, Rahel and Raquel are different characters in various respects, but their strict imprisonment within the codified whore/madonna dichotomy actually creates a bond between the two. Grillparzer's portrayal of Rahel reflects a seductive societal outsider who nonetheless bends to a state authority, a state authority unwilling to accept her otherness.

Feuchtwanger first learned of the legend through Grillparzer: "Ich liebte und liebe sehr dieses Stück, den zarten Schwung seiner Verse und die Seelenkenntnis

34. Lorenz, "Frau und Weiblichkeit", p. 215. 
seines Dichters, der bewußt darauf verzichtet, seiner Handlung irgendwelche geschichtlichen Beziehungen zu geben, dafür aber seine Menschen um so schärfer herausarbeitet." 35 If Feuchtwanger loved Grillparzer's play, as he claims, one must ask why he revised the outer attributes of Raquel so radically. Whereas Grillparzer at least attempted to show Rahel breaking away from the dictates of her father, Feuchtwanger returns his Raquel to this domain. By shifting the emphasis of the male authority from the state to the family, he has perhaps returned to an even more primitive state of domination over women. From my reading of the text, Feuchtwanger must have felt a need to reassert Judaism among the world religions after the Holocaust and, in so doing, reestablish its authority. ${ }^{36} \mathrm{He}$ accomplishes this by returning power from the state to the father. Familial authority, and with it its religious affiliation, is renewed in the relationship between father and daughter.

Despite these differences in Grillparzer's and Feuchtwanger's motivations, their depictions of the Jewesses remain embedded within a literary tradition unchallenged by both authors. Rahel and Raquel represent a skewed view of women. This view had been perpetuated over time and kept them locked in an image which even sensitive authors such as Grillparzer and Feuchtwanger were unable to shed.

35. Feuchtwanger, Nachwort p. 465.

36. Manuel Wiznitzer thinks that the conversations between Rodrigue, the Christian, Musa Ibn Da'ud, the Muslim, and Benjamin, the Jew, are reminiscent of the ring parable in Lessing's Nathan der Weise. See Manuel Wiznitzer, "Die Jüdin von Toledo: Feuchtwangers Rückkehr zur jüdischen Thematik" in: Lion Feuchtwanger: Materialien zu Leben und Werk, ed. Wilhelm von Sternburg, Frankfurt/M 1989, p. 261. 